\title{
ANALYSIS OF THE EFFECT OF APPLICATION DESIGN, CUSTOMER SERVICE, SECURITY AND PRIVACY, AND FULFILMENT DIMENSIONS TO CUSTOMER SATISFACTION AND REPURCHASE INTENTION OF BLIBLI.COM CUSTOMERS IN SURABAYA
}

\author{
Janice Carysa Siahaya ${ }^{\mathrm{a} *}$, Amelia $^{\mathrm{b}}$, Ronald Suryaputra ${ }^{\mathrm{c}}$ \\ ajanicecarysa@gmail.com \\ ${ }^{a}$ Master of Management Student at Pelita Harapan University, Surabaya 60234, Indonesia \\ ${ }^{b, c}$ The Lecturer of Master of Management at Pelita Harapan University, Surabaya 60234, Indonesia
}

\begin{abstract}
Electronic commerce (E-commerce) is the activities of distributing, selling, buying and marketing of a produk (goods and service) by utilizing the telecommunication network such as the internet. In brief, e-commerce is the process of buying and selling product electronically. In 2020, internet has played an important role in human life. This is proven by the increase of internet users in the world within the last 3 years. The internet use is constantly increasing, beside being used to meet communication needs, internet also became a new breakthrough where costumers can shop with e-commerce which has spread through out Indonesia. Therefore, the presence of Blibli.com has big impact in the development of the ecommerce industry, particullarly in Surabaya. This research aims to analyze the impact of variables: aplication design, customer service, security and privacy and fulfillment on the repurchase intention through customer satisfaction of Blibli.com customers in Surabaya. The sample used in this research was 255 respondens both male and female respondents, domiciled in Surabaya, with the age range of $18-60$ years. The questionnaire was given to the respondents who had installed Blibli.com apps in the last 6 months, active in seeking product information through Blibli.com application for the last 6 months, ever bought and used product from Blibli.com apps minimum twice in the last 6 months, knowing various promotion offered by Blibli.com apps, ever contact Blibli.com customer service in the last 6 months, knowing the return policy from Blibli.com, knowing various offers in connection with the delivery service from Blibli.com (example: dropshipper, various delivery service). Processing and analyzing data in this research used SPSS 22.0. The next step was tabulating the results of the responded researchfollowed by conducting a test of the research model using data analyse technic, Structural Equation Model (SEM). Empitical findings indicated that there is application design has a significant relationship towards customer satisfaction with reggresion coefficient of 0.288 with C.R value of 4.301; customer service has significant effect towards customer satisfaction with coefficient of reggresion of 0.310 with C.R value of 4.167; security and privacy is sifnificant towards customer satisfaction with coefficient of reggresion of 0.292 and C.R value of 4.215; fulfillmentis significant towards customer satisfaction with coefficient of reggresion of 0.210 and C.R value of 3.075; customer satisfaction has a significant effect on repurchase intention with coefficient of reggresion of 0.661 and C.R value of 9.420 .
\end{abstract}

Keywords: Application Design, Customer Service, Security and Privacy, Fulfillment, Customer Customer Satisfaction, Repurchase Intention, E-Commerce

\section{Introduction}

The needs of the world community are currently experiencing major changes due to the influence of globalization. The impact of globalization that causes significant differences is the development of technology. Technology is very important in today's digital era, where technology is a means or system that functions to provide comfort and convenience for its users. Technology that plays an important role in providing comfort and convenience is the internet. The internet network is developing so rapidly to accompany the development of an increasingly sophisticated technology world (kompasiana.com, downloaded on May 16, 2020). The internet connects one person to another, provides information, becomes a means of entertainment, and as a means of communication. This makes the internet a basic necessity for most 
of its users. According to Laudon (2007) there are six reasons why internet technology is slowly becoming a basic necessity for society in today's digital era. The sixth reason is the internet connectivity and extensive reach, reduce communication costs, lower transaction costs, interactive, flexible and convenient, and has the ability to distribute knowledge quickly.

In the last three years from 2017, Internet users in the world experiencing rapid growth. According to data released we are social as of August 2017, the number of global internet users touched 3.8 billion with a penetration of $51 \%$ of the total population in the world. From year to year, the number of internet users continues to grow significantly. Internet users around the world in 2020 have reached 4.5 billion people. This figure shows that internet users have reached more than $60 \%$ of the world's population (wearesocial.com, downloaded on May 16, 2020). Indonesia is one of the countries with the highest internet access in the world. As a country located in the Asia Pacific region, Indonesia is part of the 4.3 billion total population in the Asia Pacific region. More than half of the population, about $56 \%$ or 2.42 billion of them already have internet access. According to wearesocial.com, Indonesia is in third place with a population growth that accesses the internet by $17 \%$ in the past year. This figure is equal to 25.3 million new internet users in a year (wearesocial.com, downloaded on May 16, 2020).

According to Dharma (2006) the use of the internet is not only used to search for information, global communication, and publications, but also as a means of economic transactions which is better known as ecommerce. E-commerce is all electronic trading activities where there is a process of buying, selling, exchanging goods and services between two parties, all of which are carried out online via the internet network. To compete in the era of free trade, business people must take advantage of the existence of ecommerce. Regardless of the scale of the business being run by utilizing the internet, e-commerce is an opportunity to accelerate business development (kolomsatu.com, downloaded on May 17, 2020).

To target the e-commerce business opportunity, many online shops are managed individually. However, there is also a large e-commerce business that is the pioneer of the first online shopping mall in Indonesia and has been named "The 1st Champion of Indonesia Original Brand 2017" which is an award event for "Indonesia Original Brands 2017". The pioneer is Blibli.com. Blibli.com is committed to providing a safe, comfortable, easy, fun online shopping experience anywhere and anytime for its customers. As an online store that is founded and managed by Indonesians, the name Blibli is inspired by the Indonesian word "Beli" which represents shopping activities that are the main chain of this online shopping mall. "Big Choices Big Deals", which is the tagline of Blibli.com, represents a dynamic, modern, and energetic Blibli.com to provide an easy and multiple choice online shopping solution, with a variety of attractive choices. (blibli.com, downloaded on 17 May 2020).

Repurchase intentions presented the possibility that their customer's desire to buy a product in the future. When an increase in repurchase intentions means there will be also an increase in the likelihood of purchase. Customer repurchase intention to repurchase is one of the most important things for e-commerce companies to achieve profit (media.neliti.com, downloaded May 17, 2020). This research was made to find out about how Customer Satisfaction effects Repurchase Intention. Through this research, we can also find out how Application Design can affect Customer Satisfaction, how Customer Service affects Customer Satisfaction, how Security and Privacy affects Customer Satisfaction and how Fulfilment affects Customer Satisfaction.

\section{Litterature Review}

\subsection{Theories and Hypotheses}

\subsubsection{Application Design}


According to Liu and Arnett (2016), a successful application is an application design that attracts customers, making them feel that the application is trustworthy, reliable, which will generate customer satisfaction. According to Carlos et al (2009) customer satisfaction can be achieved by attractive application design graphic presentations such as icons, colors, images and animations, giving the application a higher clarity. The results of the study by Montoya-Weiss et al. (2003) show that various application design factors affect the perception of service quality, which in turn affects customer satisfaction.

Hypothesis 1: Application Design has a positive and significant effect on Customer Satisfaction.

\subsubsection{Customer Service}

According to Kasmir (2003), customer service in general is any activity that is intended or aimed at providing customer satisfaction, through services that can fulfill customer wants and needs. The higher the customer satisfaction felt by consumers, the stronger the repurchase intention of the consumer, and vice versa, if the level of customer satisfaction from the previous purchase is low, the repurchase intention will also be low (Choi and Kim, 2013). According to Sugiarthi et al., (2014), the level of customer satisfaction can occur after experiencing whether the customer service that the customer expects is fulfilled or exceeded if the customer feels happy and happy after receiving the service provided it will lead to customer satisfaction.

Hypothesis 2: Customer Service has a positive and significant effect on Customer Satisfaction.

\subsubsection{Security and Privacy}

From the point of view of relationship quality, security and privacy have been shown to have a positive impact on customer satisfaction (Casalo et al., 2008; Kim et al., 2009). Transaction security in an electronic environment has also been shown to be an important predictor of customer satisfaction (Szymanski and Hise, 2000). In particular, security assurance plays an important role in building customer trust and satisfaction with online retailers by reducing customer concerns about misuse of personal data and vulnerability of transaction data (Hoffman et al., 1999; Jarvenpaa and Todd, 1997).

Hypothesis 3: Security and Privacy has a positive and significant effect on Customer Satisfaction.

\subsubsection{Fulfilment}

The results of the study by Wolfinbarger and Gilly (2013) show that internal fulfillment is the most prominent factor in assessing the level of customer satisfaction compared to other retail quality dimensions. Semeijn et al., (2005) also stated that fulfillment was found to affect customer satisfaction. According to Oliver (1997) fulfillment is defined as a perception that fulfills customer satisfaction in relation to customer transactions. Jin and Swinney (2009) found that fulfillment is the most important factor in determining customer satisfaction. Furthermore, Yen and $\mathrm{Lu}$ (2008) found that customer perceptions of fulfillment are positively related to customer satisfaction in the context of e-commerce.

Hypothesis 4: Fulfilment has a positive and significant effect on Customer Satisfaction.

\subsubsection{Customer Satisfaction}

Pusparani and Rastini, (2014) found that there are two main variables that determine customer satisfaction, namely expectations and perceived performance, if the perceived performance exceeds the expectations or expectations of the customer, the customer will feel satisfied with the product or suit, but if the opposite is true, then the customer will feel dissatisfied and there will be a movement of them or the goods and services that have been used so far. According to research conducted by Fang, et al (2011), it shows that customer 
satisfaction has a positive effect on repurchase intention. Liao et al. (2016) found that customer satisfaction has a significant impact on repurchase intention in various services.

\section{Hypothesis 5: Customer Satisfaction has a positive and significant effect on Repurchase Intention.}

\subsection{Research Model}

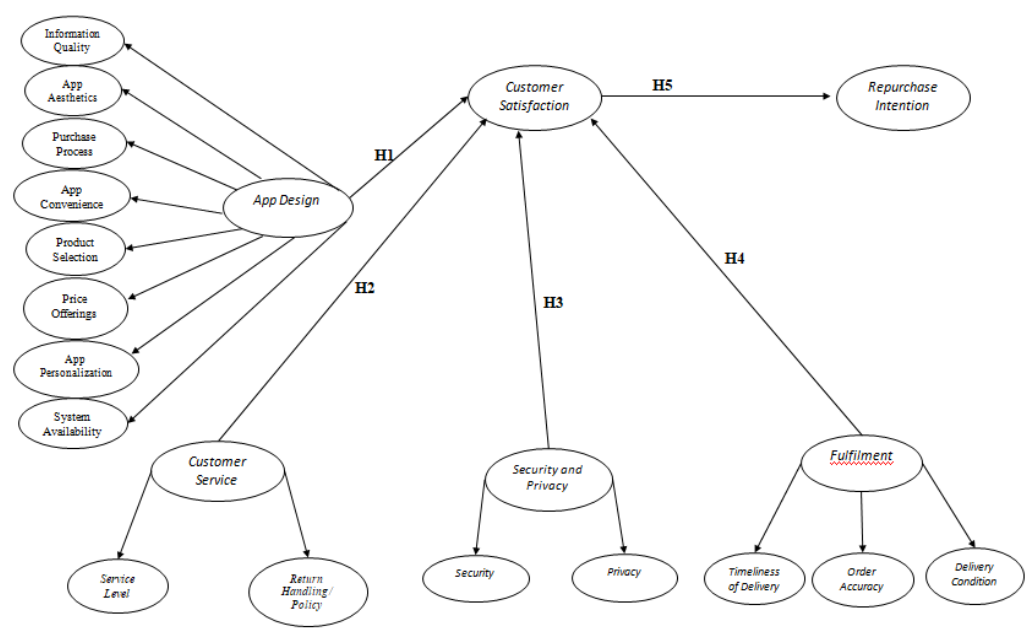

Figure 2.1: The Framework of Research Model

\section{Research Methods}

This research is causal research, because it is used to develop existing research models to test the research hypotheses that are determined based on literature review to answer the problems identified in the previous chapter. The research method used in this study is a quantitative method, where this method is a scientific approach to managerial and economic decision making. The method used in this study will refer to references that can carry out a simultaneous analysis process associated with a multi-variable research model, the Structural Equation Model (SEM). The program used is the AMOS 22.0 software program. This chapter describes the object of research directed at analyzing models about the relationship between variables to understand the factors that influence Repurchase Intention from Blibli.com customers in Surabaya. The sampling method used in this research is non-probability sampling. This study uses a questionnaire as the main tool in data collection. In this study, researchers will use a purposive sampling technique, where researchers determine respondents who will help researchers to distribute and fill out questionnaires. The area used as a place for distributing questionnaires was the Surabaya city, so that respondents were selected according to the criteria determined in this study. The sample used in this research was 255 respondens both male and female respondents, domiciled in Surabaya, with the age range of $18-60$ years years where the age is an early adulthood (Kotler and Armstrong, 2010). The questionnaire was given to the respondents who had installed Blibli.com apps in the last 6 months, active in seeking product information through Blibli.com application for the last 6 months, ever bought and used product from Blibli.com apps minimum twice in the last 6 months, knowing various promotion offered by Blibli.com apps, ever contact Blibli.com customer service in the last 6 months, knowing the return policy from Blibli.com, knowing various offers in connection with the delivery service from Blibli.com (example: dropshipper, various delivery service). There are 51 
indicators used in this study indicators, from the number of existing indicators, the minimum number of samples used is 255-510 respondents, and for this research the number of respondents is 255 people. The sample used for research was 255 respondents. Data collection is done by distributing questionnaires to respondents in accordance with the characteristics of the sample that has been described previously. After completing the questionnaire, the respondent returns the questionnaire that has been filled out and will then be selected by the researcher. The selected questionnaire is a questionnaire that is completely filled out and according to the filling instructions. After selection, the selected questionnaire will be further processed. After the data is tabulated, then the research model will be tested using AMOS software version 22.0. The questionnaire in this study will be divided into two parts. The first part contains questions to get general information about the respondent himself that is useful to determine the suitability of the characteristics of the respondents with the sample criteria. The second part contains questions to obtain research data and analyze the effect of Application Design, Customer Service, Security and Privacy, Fulfillment on Repurchase Intention through Customer Satisfaction. The scale used in this study is a Likert Scale, where the answer is provided at intervals from 1=Strongly Disagree (STS) to 5=Strongly Agree (SS). Statements are made using a scale of 1-5 to obtain internal data.

\section{Result and Discussion}

\subsection{Assessment of Measurement Model}

Table 4.1: Regression Weights Full Structural Equation Model

\begin{tabular}{|c|c|c|c|c|c|c|c|}
\hline & & & Estimate & S.E. & C.R. & $\mathbf{P}$ & $\begin{array}{c}\text { Std. } \\
\text { Estimate }\end{array}$ \\
\hline \multirow{5}{*}{$\begin{array}{l}\text { Customer_Satisfaction } \\
\text { Customer_Satisfaction } \\
\text { Customer_Satisfaction } \\
\text { Customer_Satisfaction } \\
\text { PP }\end{array}$} & \multirow{2}{*}{$\begin{array}{l}\leftarrow \\
\leftarrow\end{array}$} & Customer_Service & 0.124 & 0.030 & 4.167 & $* * *$ & 0.310 \\
\hline & & Security_and_Privacy & 0.117 & 0.028 & 4.215 & $* * *$ & 0.292 \\
\hline & $\leftarrow$ & Fulfilment & 0.084 & 0.027 & 3.075 & .002 & 0.210 \\
\hline & $\leftarrow$ & App_Design & 0.115 & 0.027 & 4.301 & $* * *$ & 0.288 \\
\hline & $\leftarrow$ & App_Design & 0.207 & 0.029 & 7.180 & $* * *$ & 0.493 \\
\hline $\mathrm{AA}$ & $\leftarrow$ & App_Design & 0.222 & 0.026 & 8.572 & $* * *$ & 0.621 \\
\hline IQ & $\leftarrow$ & App_Design & 0.312 & 0.028 & 11.137 & $* * *$ & 0.892 \\
\hline SL & $\leftarrow$ & Customer_Service & 0.292 & 0.034 & 8.480 & $* * *$ & 0.785 \\
\hline RHP & $\leftarrow$ & Customer_Service & 0.252 & 0.034 & 7.358 & $* * *$ & 0.848 \\
\hline $\mathrm{S}$ & $\leftarrow$ & \multirow{2}{*}{$\begin{array}{l}\text { Security_and_Privacy } \\
\text { Security_and_Privacy }\end{array}$} & 0.316 & 0.038 & 8.301 & $* * *$ & 0.895 \\
\hline $\mathrm{P}$ & $\leftarrow$ & & 0.344 & 0.038 & 9.160 & $* * *$ & 0.910 \\
\hline $\mathrm{DC}$ & $\leftarrow$ & Fulfilment & 0.342 & 0.028 & 12.133 & $* * *$ & 0.905 \\
\hline TOD & $\leftarrow$ & \multirow{2}{*}{$\begin{array}{l}\text { Fulfilment } \\
\text { Fulfilment }\end{array}$} & 0.360 & 0.029 & 12.522 & $* * *$ & 0.940 \\
\hline $\mathrm{OA}$ & $\leftarrow$ & & 0.375 & 0.028 & 13.290 & $* * *$ & 0.920 \\
\hline PS & $\leftarrow$ & App_Design & 0.301 & 0.027 & 10.966 & $* * *$ & 0.969 \\
\hline $\mathrm{AC}$ & $\leftarrow$ & App_Design & 0.353 & 0.027 & 12.917 & $* * *$ & 0.979 \\
\hline $\mathrm{PO}$ & \multirow{2}{*}{$\begin{array}{l}\leftarrow \\
\leftarrow\end{array}$} & \multirow{2}{*}{$\begin{array}{l}\text { App_Design } \\
\text { App_Design }\end{array}$} & 0.374 & 0.027 & 13.913 & $* * *$ & 0.981 \\
\hline SA & & & 0.293 & 0.028 & 10.547 & $* * *$ & 0.689 \\
\hline $\mathrm{AP}$ & $\leftarrow$ & App_Design & 0.326 & 0.028 & 11.695 & $* * *$ & 0.862 \\
\hline Repurchase_Intention & $\leftarrow$ & Customer_Satisfaction & 0.677 & 0.072 & 9.420 & $* * *$ & 0.661 \\
\hline $\mathrm{CS} 2$ & $\leftarrow$ & Customer_Satisfaction & 0.926 & 0.066 & 14.058 & $* * *$ & 0.785 \\
\hline
\end{tabular}




\begin{tabular}{|c|c|c|c|c|c|c|c|}
\hline & & & Estimate & S.E. & C.R. & $\mathbf{P}$ & $\begin{array}{c}\text { Std. } \\
\text { Estimate }\end{array}$ \\
\hline IQ2 & $\leftarrow$ & IQ & 1.012 & 0.087 & 11.582 & $* * *$ & 0.709 \\
\hline IQ1 & $\leftarrow$ & IQ & 1.000 & & & & 0.701 \\
\hline AA3 & $\leftarrow$ & AA & 0.951 & 0.091 & 10.497 & $* * *$ & 0.710 \\
\hline $\mathrm{AA} 2$ & $\leftarrow$ & AA & 1.035 & 0.101 & 10.213 & $* * *$ & 0.743 \\
\hline AA1 & $\leftarrow$ & $\mathrm{AA}$ & 1.000 & & & & 0.759 \\
\hline IQ3 & $\leftarrow$ & IQ & 1.055 & 0.100 & 10.504 & $* * *$ & 0.741 \\
\hline PP3 & $\leftarrow$ & PP & 0.982 & 0.076 & 12.991 & $* * *$ & 0.857 \\
\hline PP2 & $\leftarrow$ & PP & 0.535 & 0.071 & 7.500 & $* * *$ & 0.454 \\
\hline PP1 & $\leftarrow$ & PP & 1.000 & & & & 0.865 \\
\hline $\mathrm{AC} 3$ & $\leftarrow$ & $\mathrm{AC}$ & 0.981 & 0.088 & 11.178 & $* * *$ & 0.717 \\
\hline $\mathrm{AC} 2$ & $\leftarrow$ & $\mathrm{AC}$ & 0.976 & 0.088 & 11.145 & $* * *$ & 0.719 \\
\hline $\mathrm{AC} 1$ & $\leftarrow$ & $\mathrm{AC}$ & 1.000 & & & & 0.730 \\
\hline PS3 & $\leftarrow$ & PS & 1.188 & 0.116 & 10.277 & $* * *$ & 0.743 \\
\hline PS2 & $\leftarrow$ & PS & 1.062 & 0.098 & 10.825 & $* * *$ & 0.674 \\
\hline PS1 & $\leftarrow$ & PS & 1.000 & & & & 0.649 \\
\hline $\mathrm{PO} 3$ & $\leftarrow$ & $\mathrm{PO}$ & 0.926 & 0.077 & 11.948 & $* * *$ & 0.729 \\
\hline $\mathrm{PO} 2$ & $\leftarrow$ & $\mathrm{PO}$ & 0.953 & 0.078 & 12.230 & $* * *$ & 0.738 \\
\hline $\mathrm{PO} 1$ & $\leftarrow$ & PO & 1.000 & & & & 0.767 \\
\hline AP3 & $\leftarrow$ & AP & 0.985 & 0.085 & 11.613 & $* * *$ & 0.747 \\
\hline AP2 & $\leftarrow$ & AP & 1.076 & 0.084 & 12.855 & $* * *$ & 0.818 \\
\hline AP1 & $\leftarrow$ & AP & 1.000 & & & & 0.760 \\
\hline SA3 & $\leftarrow$ & SA & 0.771 & 0.063 & 12.186 & $* * *$ & 0.684 \\
\hline SA2 & $\leftarrow$ & SA & 1.065 & 0.061 & 17.461 & $* * *$ & 0.913 \\
\hline SA1 & $\leftarrow$ & SA & 1.000 & & & & 0.855 \\
\hline RI2 & $\leftarrow$ & Repurchase_Intention & 0.841 & 0.076 & 11.033 & $* * *$ & 0.695 \\
\hline RI3 & $\leftarrow$ & Repurchase_Intention & 1.000 & & & & 0.829 \\
\hline RI1 & $\leftarrow$ & Repurchase_Intention & 0.929 & 0.077 & 12.018 & $* * *$ & 0.771 \\
\hline CS1 & $\leftarrow$ & Customer_Satisfaction & 1.000 & & & & 0.834 \\
\hline $\mathrm{CS} 3$ & $\leftarrow$ & Customer_Satisfaction & 0.991 & 0.067 & 14.681 & $* * *$ & 0.811 \\
\hline SL1 & $\leftarrow$ & SL & 1.007 & 0.092 & 10.933 & $* * *$ & 0.756 \\
\hline SL2 & $\leftarrow$ & SL & 1.036 & 0.095 & 10.942 & $* * *$ & 0.792 \\
\hline SL3 & $\leftarrow$ & SL & 1.000 & & & & 0.749 \\
\hline RHP1 & $\leftarrow$ & RHP & 1.467 & .157 & 9.365 & $* * *$ & 0.899 \\
\hline RHP2 & $\leftarrow$ & RHP & 1.300 & 0.137 & 9.469 & $* * *$ & 0.783 \\
\hline RHP3 & $\leftarrow$ & RHP & 1.000 & & & & 0.593 \\
\hline S1 & $\leftarrow$ & $\mathrm{S}$ & 1.140 & 0.114 & 10.031 & $* * *$ & 0.807 \\
\hline $\mathrm{S} 2$ & $\leftarrow$ & S & 1.147 & 0.113 & 10.162 & $* * *$ & 0.829 \\
\hline S3 & $\leftarrow$ & $S$ & 1.000 & & & & 0.658 \\
\hline P1 & $\leftarrow$ & $P$ & 1.064 & 0.097 & 10.957 & $* * *$ & 0.736 \\
\hline
\end{tabular}




\begin{tabular}{|ccc|c|c|c|c|c|}
\hline & & & Estimate & S.E. & C.R. & P & $\begin{array}{c}\text { Std. } \\
\text { Estimate }\end{array}$ \\
\hline P2 & $\leftarrow$ & P & 0.982 & 0.091 & 10.842 & $* * *$ & 0.726 \\
\cline { 5 - 9 } P3 & $\leftarrow$ & P & 1.000 & & & & 0.743 \\
OA1 & $\leftarrow$ & OA & 0.979 & 0.068 & 14.475 & $* * *$ & 0.810 \\
OA2 & $\leftarrow$ & OA & 0.952 & 0.073 & 12.972 & $* * *$ & 0.784 \\
OA3 & $\leftarrow$ & OA & 1.000 & & & & 0.815 \\
DC1 & $\leftarrow$ & DC & 1.001 & 0.086 & 11.674 & $* * *$ & 0.763 \\
DC2 & $\leftarrow$ & DC & 0.945 & 0.084 & 11.244 & $* * *$ & 0.723 \\
DC3 & $\leftarrow$ & DC & 1.000 & & & & 0.771 \\
TOD1 & $\leftarrow$ & TOD & 0.956 & 0.092 & 10.410 & $* * *$ & 0.675 \\
TOD2 & $\leftarrow$ & TOD & 0.955 & 0.085 & 11.182 & $* * *$ & 0.731 \\
TOD3 & $\leftarrow$ & TOD & 1.000 & & & & 0.770 \\
\hline
\end{tabular}

Source: Text Output AMOS 22.0 (2020)

C.R. value for each relationship between the variables tested are shown in table 4.50. Causality relationship that occurs between variables Application Design to Customer Satisfaction, Customer Service to Customer Satisfaction, Security and Privacy to Customer Satisfaction and Fulfilment to Customer Satisfaction have a significant relationship because the C.R value is above 2.00. As for the causality relationship that occurs between the Customer Satisfaction variable to Repurchase Intention has insignificant relationship because the value of C.R is below 2.00 .

\subsection{Hypotheses Testing}

Table 4.2: Summary of Testing Results.

\begin{tabular}{|l|c|}
\hline Hypotheses & Analysis \\
\hline H1: Application Design to Customer Satisfaction & Accepted \\
\hline H2: Customer Service to Customer Satisfaction & Accepted \\
\hline H3: Security and Privacy to Customer Satisfaction & Accepted \\
\hline H4: Fulfilment to Customer Satisfaction & Accepted \\
\hline H5: Customer Satisfaction to Repurchase Intention & Accepted \\
\hline
\end{tabular}




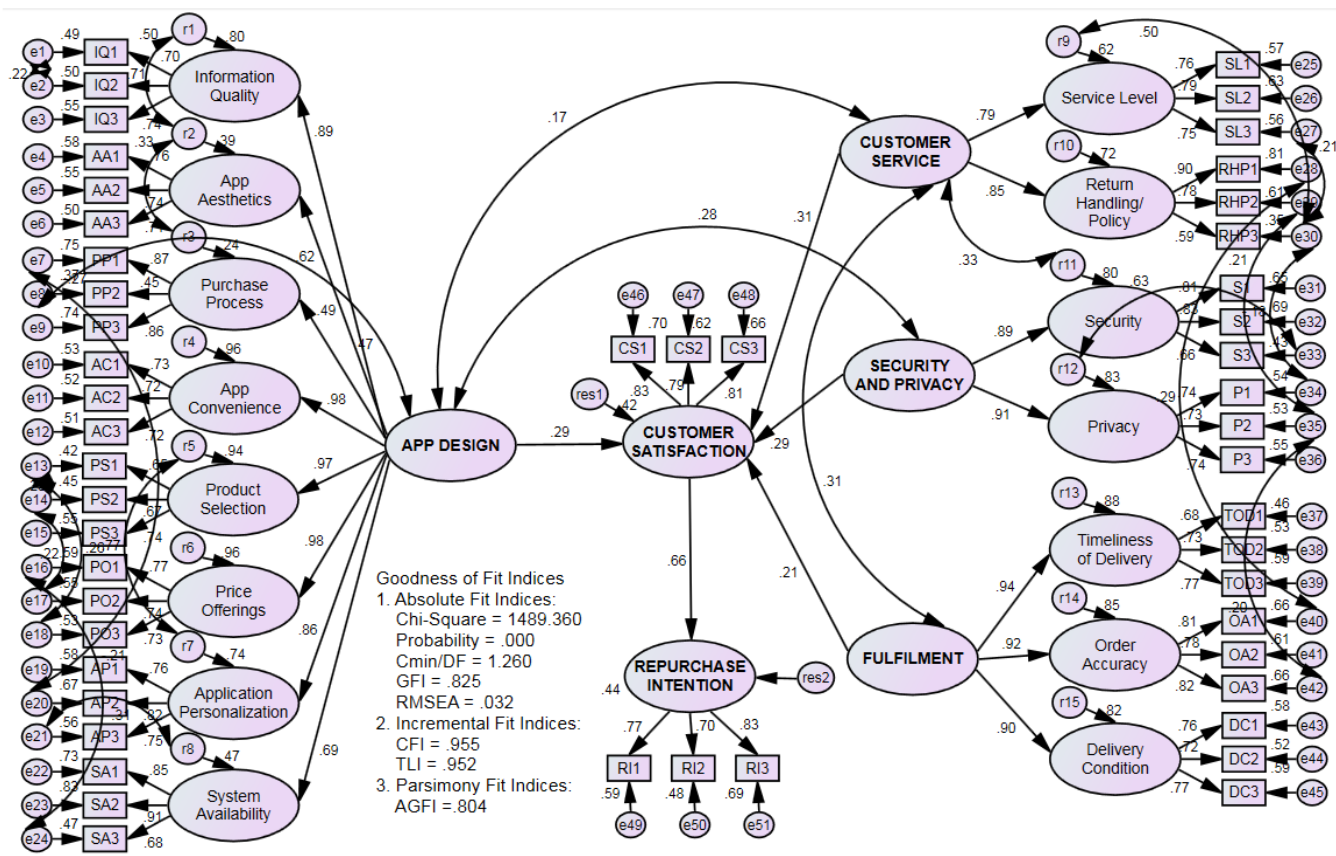

Figure 4.1 Full Structural Equation Model

\subsection{Discussion}

Based on Amos 22.0 analysis result, estimation parameters between Application Design to Customer Satisfaction, Customer Service to Customer Satisfaction, Security and Privacy to Customer Satisfaction, Fulfilment to Customer Satisfaction, and Customer Satisfaction to Repurchase Intention has a significant results in a positive direction with a value of C.R $\geqslant \pm 2.00$ with a significance level $<0.05$ (5\%), it can be said that hypothesis $\mathrm{H} 1, \mathrm{H} 3, \mathrm{H} 4$ and $\mathrm{H} 5$ were accepted. The results exhibited that all the hypothesized variables played important roles in predicting Repurchase Intention to Blibli.com on Surabaya. The findings of this study provide several important implications for Repurchase Intention research and practice, especially in e-commerce industry in the future.

\subsubsection{The effect of Application Design toward Customer Satisfaction}

The estimation parameters between Application Design and Customer Satisfaction show significant results in a positive direction with a value of C.R $=4.301$ and a regression coefficient of 0.288 with a standard hypothesis that can be accepted that is C.R. $\geqslant \pm 2.00$ with a significance level $<0.05$ (5\%), it can be said that hypothesis 1 (H1) is accepted. Application Design variable is an important element for customers as a process to improve Customer Satisfaction Identification on Blibli.com in Surabaya. The first dimension of the application design variable, namely price offerings, the way to increase the indicators of the price offerings dimension is to create an online shopping campaign in the form of a TV show by inviting Indonesian or international artists or musicians who are popular among young people while offering discounted prices at the Blibli.com application during the TV show, providing various types of subscription packages, and organizing a "Brand Week" program. The second dimension of application design variable is application convenience. The way to improve application convenience dimension indicators is adding text size facilities, maintaining 
the layout of writing information and display of the Blibli.com application, and providing creative features "Find my size" (especially for fashion items). The third dimension of the application design variable, namely product selection, is a way to improve the dimensions of the product selection indicators by providing a preorder feature, providing a brand line up on the front page of the application, and adding choices in the categories available in the Blibli.com application. Additional categories include books, music, DVD and movies, collectibles and art, business and industrial, and pet supplies. The fourth dimension of the application design variable is information quality. The way to improve the indicators of the information quality dimension is to provide a "Feed" page on the Blibli.com application which functions like social media, adding several language choices in the Blibli.com application. and provides live streaming features. Where this feature allows sellers to create live streaming sessions that aim to promote the seller's shop and products directly to Blibli.com application customers. The fifth dimension of the application design variable, namely application personalization, is a way to improve the dimensions of application personalization indicators is to provide a means where customers can communicate directly with sellers from online stores through private chat between sellers and customers, present augmented reality (AR) features, hold giveaway relies on social media. The sixth dimension of the application design variable is system availability. The way to increase the system availability dimension indicators is by providing an "Up To Date" column on the front page of the Blibli.com application, providing quick comments, and presenting the 'Image Search' feature. The seventh dimension of the application design variable, namely application aesthetics, is the way to improve application aesthetics dimension indicators by presenting custom features, presenting fun interactive programs with customers such as Blibli.com shakes, and maintaining a combination of blue and white shades in the Blibli.com application. The eighth dimension of the application design variable, namely the purchase process, is the way to improve the indicators for the purchase process dimension by providing a "saving" feature, providing a paylater feature, and adding a purchase process instruction icon on the front page of the Blibli.com application.

\subsubsection{The effect of Customer Service toward Customer Satisfaction}

The estimation parameters between Customer Service and Customer Satisfaction show significant results in a positive direction with a value of C.R $=4.167$ and a regression coefficient of 0.310 with a standard hypothesis that can be accepted that is C.R. $\geqslant \pm 2.00$ with a significance level $<0.05(5 \%)$, it can be said that hypothesis 2 (H2) is accepted. Customer Service variable is an important element for customers as a process to improve Customer Satisfaction on Blibli.com in Surabaya. The first dimension of the Customer Service variable, namely return handling / policy, as for the way to improve the return handling / policy dimension indicators is to provide the BliBli express service courier option to retrieve the product you want to return, providing clear information at the beginning about the product return stages where each stage has a deadline. both for sellers and customers, and adding the option of extended warranty since not all products are used in a short time. The second dimension of the Customer Service variable, namely service level, is the way to improve service level dimension indicators by presenting smart chatbots, providing features that function as personal customer service for customers, and improving services regarding the latest information and increasing activity in various Blibli.com social media.

\subsubsection{The effect of Security and Privacy toward Customer Satisfaction}

The estimation parameters between Security and Privacy and Customer Satisfaction show significant results in a positive direction with a value of C.R $=4.215$ and a regression coefficient of 0.292 with a standard hypothesis that can be accepted that is C.R. $\geqslant \pm 2.00$ with a significance level $<0.05(5 \%)$, it can be said that 
hypothesis 3 (H3) is accepted. Security and Privacy variable is an important element for customers as a process to improve Customer Satisfaction Blibli.com in Surabaya. The first dimension of the Security and Privacy variable, namely Privacy, is a way to increase the indicators of the Privacy dimension by paying attention to the transmissions used when customers make transactions with Blibli.com, providing education to Blibli.com employees, especially administrators, about how important it is to maintain customer privacy, and impose severe sanctions on administrators who intend to misuse customers' personal information, and hinder the information security management system certification on the application page. Blibli.com has received an information security management system certification in the form of ISO / IEC 27001: 2013. The second dimension of the Security and Privacy variable, namely Security, as for the way to increase the indicators of the Security dimension is to blacklist problematic sellers or customers, use a password in the form of a security code or face recognition, and attach a payment gateway that already has PCI DSS certificate when the customer will make a payment on the Blibli.com application.

\subsubsection{The effect of Fulfilment toward Customer Satisfaction}

The estimation parameters between Fulfilment and Customer Satisfaction show significant results in a positive direction with a value of C.R $=3.075$ and a regression coefficient of 0.210 with a standard hypothesis that can be accepted that is C.R. $\geqslant \pm 2.00$ with a significance level $<0.05(5 \%)$, it can be said that hypothesis 4 (H4) is accepted. Fulfilment variable is an important element for customers as a process to improve Customer Satisfaction on Blibli.com in Surabaya. The first dimension of the Fulfilment variable, namely timeless of delivery, is the way to improve the timeless of delivery dimension indicators by improving the facilities from Blibli.com with additional information for customers from delivery such as when the recipient of the product is delivered away, the information is recorded in the Blibli system. .com and Blibli.com also help customers to arrange return delivery schedules, Blibli.com can precisely track buyer orders by matching the system with the delivery party and facilitating messages from buyers to delivery parties, and presenting express delivery in the form of one hour delivery. The second dimension of the Fulfilment variable, namely order accuracy, as for the way to increase the order accuracy dimension indicators is to facilitate so that the seller can provide receipt numbers not only in the form of numbers but also in the form of barcodes, providing information to buyers that every time they open a product shipment from a Blibli.com seller then it needs to be recorded starting from the process of opening the box, so that if the product is not suitable, you can immediately complain, and provide customer satisfaction points where for the seller who has the highest customer satisfaction point value, the seller gets a voucher from Blibli.com and it is announced on the front of the application so that the seller and the shop online can be more famous. The third dimension of the Fulfilment variable, namely the delivery condition, is the way to improve the indicators of the delivery condition dimensions by collaborating with retail stores and presenting the On-The-Go Shopping feature, the product return guarantee period needs to be added, especially for products whose use process takes more time, and offers multiple delivery facilities. Where in this facility customers can buy several items from one online shop but want to send them to different addresses.

\subsubsection{The effect of Customer Satisfaction toward Repurchase Intention}

The estimation parameters between Customer Satisfaction and Repurchase Intention show significant results in a positive direction with a value of $C . R=9.420$ and a regression coefficient of 0.661 with a standard hypothesis that can be accepted that is C.R. $\geqslant \pm 2.00$ with a significance level $<0.05(5 \%)$, it can be said that hypothesis 5 (H5) is accepted. Customer Satisfaction variable is an important element for customers as a process to improve Repurchase Intention on Blibli.com in Surabaya. From the Customer Satisfaction variable 
that can be done to improve this variable is to provide free official Blibli.com merchandise to loyal customers who have shopped according to the minimum purchase, continue to innovate in product variations by adding various product variations in the Blibli.com application, and continue to innovate in the appearance of the application.

\section{Conclusion}

This study provides evidence that the Application Design significantly affected Customer Satisfaction, Customer Service significantly affected Customer Satisfaction, Security and Privacy significantly affected Customer Satisfaction, Fulfilment significantly affected Customer Satisfaction, and Customer Satisfaction significantly affected Repurchase Intention.

\subsection{Managerial Implications}

Table 5.1: Managerial Implications

\begin{tabular}{|c|c|}
\hline Current Research & Managerial Implications \\
\hline \multirow[t]{5}{*}{$\begin{array}{l}\text { Application Design significantly } \\
\text { affected Customer Satisfaction. }\end{array}$} & $\begin{array}{l}\text { Dimensions of Price Offerings } \\
\text { 1. Create an online shopping campaign in the form of a TV show by } \\
\text { inviting Indonesian or international artists or musicians who are } \\
\text { popular among young people while offering discounts on the } \\
\text { Blibli.com application during the TV show. } \\
\text { 2. Providing various types of subscription packages, } \\
\text { 3. Organizing the "Brand Week" program. }\end{array}$ \\
\hline & $\begin{array}{l}\text { Dimensions of Application Convenience } \\
\text { 1. Add text size facility. } \\
\text { 2. Maintain the layout of writing information and display of the } \\
\text { Blibli.com application } \\
\text { 3. Provides creative "Find my size" feature (fashion only). }\end{array}$ \\
\hline & $\begin{array}{l}\text { Dimensions of Product Selection } \\
\text { 1. Provide pre order feature. } \\
\text { 2. Provide a brand line up on the front page of the application. } \\
\text { 3. Adding options in the categories available in the Blibli.com } \\
\text { application. Additional categories include books, music, DVD and } \\
\text { movies, collectibles and art, business and industrial, and pet } \\
\text { supplies. }\end{array}$ \\
\hline & $\begin{array}{l}\text { Dimensions of Information Quality } \\
\text { 1. Provide a "Feed" page on the Blibli.com application which } \\
\text { functions like social media, } \\
\text { 2. Added several language options in the Blibli.com application. } \\
\text { 3. Provides a live streaming feature. Where this feature allows sellers } \\
\text { to create live streaming sessions that aim to promote the seller's } \\
\text { shop and products directly to Blibli.com application customers. }\end{array}$ \\
\hline & $\begin{array}{l}\text { Dimensions of Application Personalization } \\
\text { 1. Providing a means by which customers can communicate directly } \\
\text { with sellers from online stores through private chat between sellers }\end{array}$ \\
\hline
\end{tabular}




\begin{tabular}{|c|c|}
\hline & $\begin{array}{l}\text { and customers. } \\
\text { 2.Presenting the augmented reality (AR) feature. } \\
\text { 3. Organizing a giveaway relying on social media. }\end{array}$ \\
\hline & $\begin{array}{l}\text { Dimensions of System Availability } \\
\text { 1. Provide an "Up To Date" column on the front page of the } \\
\text { Blibli.com application. } \\
\text { 2. Provide quick comments. } \\
\text { 3. Presenting the 'Image Search' feature. }\end{array}$ \\
\hline & $\begin{array}{l}\text { Dimensions of Application Aesthetics } \\
\text { 1. Presenting custom features. } \\
\text { 2. Presenting fun interactive programs with customers such as } \\
\text { Blibli.com shakes. } \\
\text { 3. Maintaining the combination of blue and white tones on the } \\
\text { Blibli.com application. }\end{array}$ \\
\hline & $\begin{array}{l}\text { Dimensions of Purchase Process } \\
\text { 1. Provide a "saving" feature } \\
\text { 2. Provide paylater feature. } \\
\text { 3. Added an icon for the purchase process instruction on the } \\
\text { Blibli.com front page. }\end{array}$ \\
\hline \multirow[t]{2}{*}{$\begin{array}{l}\text { Customer Service significantly } \\
\text { affected Customer Satisfaction. }\end{array}$} & $\begin{array}{l}\text { Dimensions of Return Handling / Policy } \\
\text { 1. Providing a courier option BliBli express service can pick up the } \\
\text { product you want to return. } \\
\text { 2. Provide clear information at the start of the stages of product } \\
\text { return where each stage has a deadline for both the seller and the } \\
\text { customer } \\
\text { 3. Adding the option of extended warranty considering not all } \\
\text { products are used in a short time. }\end{array}$ \\
\hline & $\begin{array}{l}\text { Dimensions of Service Level } \\
\text { 1. Presenting the smart chatbot } \\
\text { 2. Providing features that function as a customer's personal customer } \\
\text { service. } \\
\text { 3. Improve services regarding the latest information and increase } \\
\text { activity in various social media Blibli.com. }\end{array}$ \\
\hline \multirow[t]{2}{*}{$\begin{array}{l}\text { Security and Privacy significantly } \\
\text { affected Customer Satisfaction. }\end{array}$} & $\begin{array}{l}\text { Dimensions of Privacy } \\
\text { 1. With due observance of the transmission used when a customer } \\
\text { makes a transaction with Blibli.com } \\
\text { 2. Providing education to Blibli.com employees, especially } \\
\text { administrators regarding the importance of maintaining customer } \\
\text { privacy, as well as giving severe sanctions to administrators who } \\
\text { intend to misuse customer's personal information } \\
\text { 3. Supporting information security management system certification } \\
\text { on the application page. Blibli.com has received an information } \\
\text { security management system certification in the form of ISO / IEC } \\
\text { 27001: } 2013 \text {. }\end{array}$ \\
\hline & $\begin{array}{l}\text { Dimensions of Security } \\
\text { 1. Blacklist problematic sellers or customers. } \\
\text { 2. Using a password in the form of a security code or face } \\
\text { recognition. }\end{array}$ \\
\hline
\end{tabular}




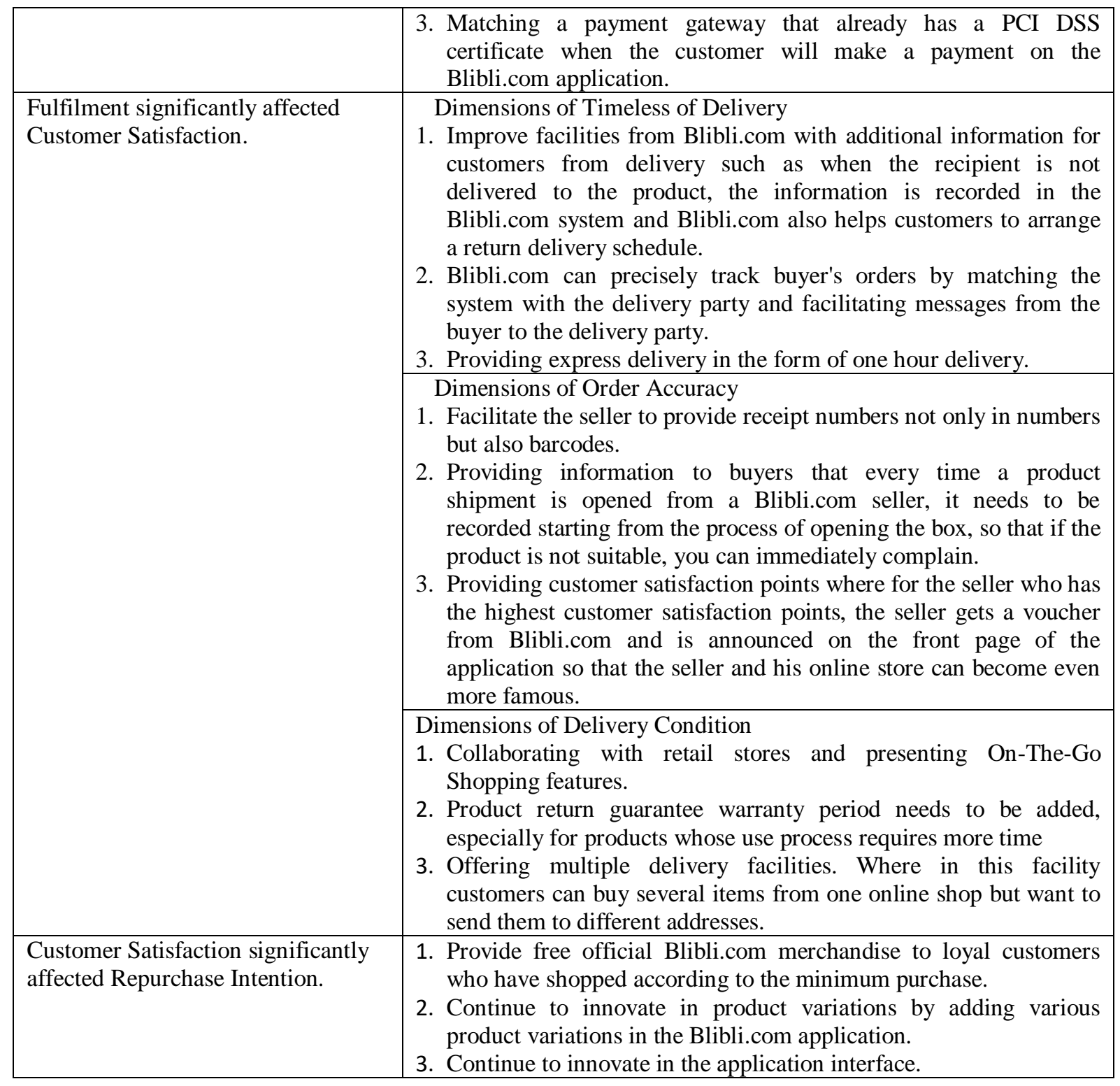

\subsection{Recommendation}

Looking at the results of existing research where there are still many limitations on the research conducted by the author, recommendations that can be submitted by the author are as follows:

- Seeing the limitations of the research object that only takes respondents namely Blibli.com customers in Surabaya, it is hoped that subsequent studies using the same or modified models can be applied to different objects to get more general results on the factors that influence Repurchase Intention. 
- Further research is expected to be able to complete the variables that already exist in this study so that it can further enhance understanding of the factors that influence Repurchase Intention that lead to trust, brand image, site revisit and word of mouth.

- Further research can be developed by linking the factors that influence repurchase intention based on customer experience. Future research can also expand the scope of respondents to be researched, or conduct their research in a different area from the current research. So that further research that is being carried out provides a broader view of repurchase intention.

\section{References}

Adolphs, C., \& Winkelmann, A. (2010). Personalization research in e-commerce-A state of the art review (2000-2008). Journal of Electronic Commerce Research, 11(4), 326.

Fornell, C. (1992). A national customer satisfaction barometer: The Swedish experience. Journal of marketing, 56(1), 6-21.

Holloway, B. B., \& Beatty, S. E. (2008). Satisfiers and dissatisfiers in the online environment: A critical incident assessment. Journal of service research, 10(4), 347-364.

Kotler, P. (2005). According to Kotler: The world's foremost authority on marketing answers your questions. Amacom Books.

Kotler, P. (2012). Kotler on marketing. Simon and Schuster.

Kotler, P., \& Keller, K. L. (2007). A framework for marketing management.

Kusdyah, I. (2012). Persepsi Harga, Persepsi Merek, Persepsi Nilai, dan Keinginan Pembelian Ulang Jasa Clinic Kesehatan (Studi Kasus Erha Clinic Surabaya). Jurnal Manajemen Pemasaran, 7(1), 25-32.

Ndubisi, N. O., \& Moi, C. T. (2005). Customers behaviourial responses to sales promotion: the role of fear of losing face. Asia Pacific Journal of Marketing and Logistics.

Park, C. W., \& Kim, J. W. (2016). An empirical research on information privacy concern in the IoT era. Journal of digital Convergence, 14(2), 65-72

Park, S., \& Ruoff, R. S. (2009). Chemical methods for the production of graphenes. Nature nanotechnology, 4(4), 217.

Price, R. M., \& Bonett, D. G. (2001). Estimating the variance of the sample median. Journal of Statistical Computation and Simulation, 68(3), 295-305.

Rajaobelina, L., \& Bergeron, J. (2009). Antecedents and consequences of buyer-seller relationship quality in the financial services industry. International Journal of Bank Marketing.

Rakesh, S., \& Khare, A. (2012). Impact of promotions and value consciousness in online shopping behaviour in India. Journal of Database Marketing \& Customer Strategy Management, 19(4), 311-320.

Robbins, L. (2007). An essay on the nature and significance of economic science. Ludwig von Mises Institute.

Rosner Klimchuk, M., \& Krasovec, S. A. (2006). Packaging Design: Successful Product Branding from Concept to Shelf. John Siley to Sons.

Shinta, K., \& Laksito, H. (2014). Pengaruh kinerja keuangan, ukuran perusahaan dan arus kas operasi terhadap earnings per share. Diponegoro Journal Of Accounting, 3(2), 682-692.

Strandvik, T., \& Liljander, V. (1994, June). Relationship strength in bank services. In Proceedings from the 1994 Research Conference on Relationship Marketing: Theory, Methods and Applications, June (pp. 11-13).

Tjiptono, F., Chandra, G., \& Adriana, D. (2012). Pemasaran strategik. Yogyakarta: Andi. 


\section{APPENDIX}

\begin{tabular}{|c|}
\hline Indicators of Information Quality \\
\hline $\begin{array}{l}\text { X1: This website provides complete information that I need in shopping. } \\
\text { X2: This website fulfills my information needs regarding product availability. } \\
\text { X3: Information on this website is effective in providing the detail information of product } \\
\text { variations. }\end{array}$ \\
\hline Indicators of Application Aesthetics \\
\hline $\begin{array}{l}\text { X4: Overall the appearance of this website is visually pleasing. } \\
\text { X5: The layout of the menu options on this website is attractive. } \\
\text { X6: The appearance of this website uses a visually attractive color combination. }\end{array}$ \\
\hline Indicators of Purchase Process \\
\hline $\begin{array}{l}\text { X7: I feel the ease in making payments online through this website. } \\
\text { X8: I feel the process of purchase in this website is easy to learn. } \\
\text { X9: I feel the ease in their shopping process via this website as there are variations of payment } \\
\text { methods offered. }\end{array}$ \\
\hline Indicators of Application Convenience \\
\hline $\begin{array}{l}\text { X10: I feel that this website features content that makes it easy for me to read. } \\
\text { X11: I feel that the way of conveying information on this website makes it easier for me to get } \\
\text { information. } \\
\text { X12: I find the layout of the information writing on this website easy to understand. }\end{array}$ \\
\hline Indicators of Product Selection \\
\hline $\begin{array}{l}\text { X13: I can complete all my needs through this website. } \\
\text { X14: This website has an interesting selection of product categories. } \\
\text { X15: This website has an interesting range of product lines. }\end{array}$ \\
\hline Indicators of Price Offerings \\
\hline $\begin{array}{l}\text { X16: This website offers a variety of attractive sales promotions. } \\
\text { X17: This website offers a variety of products at competitive prices. } \\
\text { X18: This website provides attractive offers regarding delivery of goods. }\end{array}$ \\
\hline Indicators of Application Personalization \\
\hline $\begin{array}{l}\text { X19: This website allows me to interact with the customer service directly. } \\
\text { X20: This website has interactive features in communicating directly with sellers. } \\
\text { X21: I can interact with this website to get information tailored to my specific needs. }\end{array}$ \\
\hline Indicators of System Availability \\
\hline $\begin{array}{l}\text { X22: I can go to this website promo menu quickly because the front page of this website has been } \\
\text { given the features of the current promo. } \\
\text { X23: I can quickly open the menu on this website because the front page of the website has been } \\
\text { given a selection of popular product features. } \\
\text { X24: This website finds the information I need quickly by using the search feature. }\end{array}$ \\
\hline Indicators of Service Level \\
\hline $\begin{array}{l}\text { X25: The customer service of this website can provide the information that customers need } \\
\text { exactly. } \\
\text { X26: This website has customer service representatives available online who serve the customers } \\
\text { well. } \\
\text { X27: Customer service website is responsive in helping to resolve the problems faced by } \\
\text { customers. }\end{array}$ \\
\hline
\end{tabular}


Indicators of Return Handling / Policy

X28: This website provides me with a convenient option to return items that I have purchased.

X29: This website provides clear product return information.

$\mathrm{X} 30$ : This website offers a meaningful guarantee.

$$
\text { Indicators of Security }
$$

X31: I feel safe in my transactions with this website.

$\mathrm{X} 32$ : This website has adequate security features.

X33: This website protects information about my credit card. Indicators of Privacy

X34: I believe this website maintain the security of my personal information.

X35: I believe the administrator of this website will not misuse my personal information.

$\mathrm{X} 36$ : This website protects information about my shopping behavior.

$$
\text { Indicators of Timeless of Delivery }
$$

X37: This website system helps ensure products are delivered according to the promised timeframe.

X38: Systems of this website helped me track my order to insure the delivered goods to arrive within the promised.

X39: This website system helps ensure that my booking confirmation is well responded to within the stipulated time.

Indicators of Order Accuracy

X40: The seller on this website sends the product that matches the order I made through this website.

X41: The seller on this website sends the number of items that match the order I made through this website.

X42: The seller on this website enters the correct receipt number so that I can track the information on the whereabouts of the product I ordered.

Indicators of Delivery Condition

X43: This website provides a guaranteed product return guarantee that makes it easy for customers.

X44: This website offers attractive flexibility for shipping goods to different locations of the customer.

X45: This website provides a wide selection of shipping services that make it easier for customers to choose the delivery that suits their needs.

Y1: Overall, I am satisfied with this website. Indicators of Customer Satisfaction

Y2: I am satisfied with the attractive appearance of this website.

Y3: I am satisfied with the variety of products offered by this website. Indicators of Repurchase Intention

Y4: I will make more purchases through this website in the future.

Y5: I will increase the variety of products that I purchased through this website in the future.

Y6: I will make this website my main shopping place for my various needs. 